\title{
Neurophysiological Evaluation ff Paresthetic Notalgia
}

\author{
Lisiane T Ganassin ${ }^{1}$ and José Antonio Garbino*2 \\ ${ }^{1}$ Clinical Neurophysiology Education Program, Instituto Lauro de Souza Lima, Bauru, São Paulo, Brazil \\ ${ }^{2}$ Department of Clinical Neurophysiology Education Program, Instituto Lauro de Souza Lima, Bauru, São Paulo, Brazil
}

Submission: August 11, 2018; Published:September 18, 2018

*Corresponding author: José Antonio Garbino, Department of Clinical Neurophysiology Education Program, Instituto Lauro de Souza Lima, Bauru, São Paulo, Brazil; Email: ja.garbino@gmail.com

\section{Abstract}

Despite being a diagnosis little known to general physicians, paresthetic notalgia is a frequent complaint in dermatology clinic. The correlation with degenerative changes in the thoracic spine is somewhat known, but the electrophysiological study in these cases is still unfamiliar to the neurophysiologist. The objective of this paper is to present a clinical case, describe and discuss the neurophysiological evaluation of a patient with paresthetic notalgia.

Keywords: Diagnosis; physicians; paresthetic notalgia; Dermatology clinic; Hyperpigmentation

\section{Introduction}

Paresthetic Notalgia (PN) is a frequent reason for searching a dermatology clinic. Due to the correlation of PN with degenerative changes of the thoracic spine, neurophysiological evaluation has been requested, but it is still an unusual entity for the neurophysiologist. Paresthetic notalgia has been referred as: "dorsal pruritus with hyperpigmentation", "pruriginous dorsal melanosis", "Pierini and Borda melanocytic pruritus" [1], "localized hereditary pruritus", "pigmented posterior pruritic spot" and "pruritus subscapular"[1,2]. For a long period it was considered as one of the clinical varieties of primary cutaneous amyloidosis receiving the name "dorsal amyloid lichen"[2]. It is now known that the presence of amyloid substance is a consequence of pruritus and itching $[1,3]$. Paresthetic Notalgia is considered as a chronic sensory neuropathy affecting in particular the interscapular region between T2 to T6 levels, unior bilateral, and may present a wider distribution $[1,2]$.

\section{Clinical Case}

A 47-year-old female patient, who reported dark spots on the upper dorsal region in both sides and on the lower right dorsal region, accompanied by intense local pruritus, with a fiveyear evolution. Background: chronic back pain and low back pain for 16 years.

The dermatological examination showed hyperchromic macules in the upper dorsal region bilaterally and the lower dorsal region on the right side, Figure 1. Normal nerve palpation; deep reflexes normal and symmetric; sensory mapping: tactile, termal and pain sensory modalities preserved, Figure 2. Image examination: X-ray shows mild left dorsal scoliosis, without significant kyphosis, Figure 3.

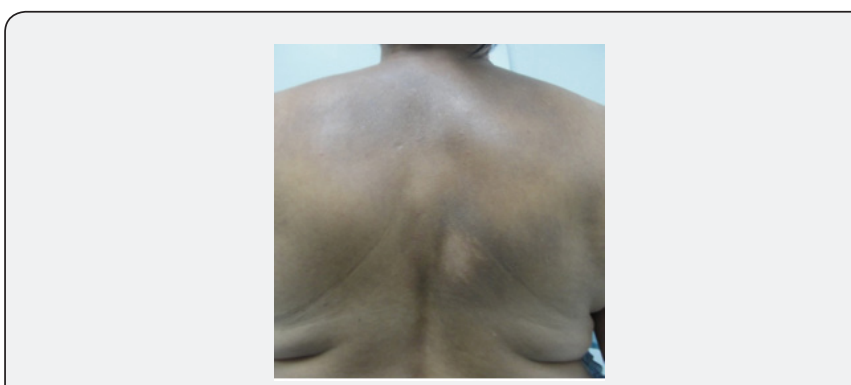

Figure 1: Hypercromic macules in the upper dorsal region bilaterally and the lower dorsal region on the right side.

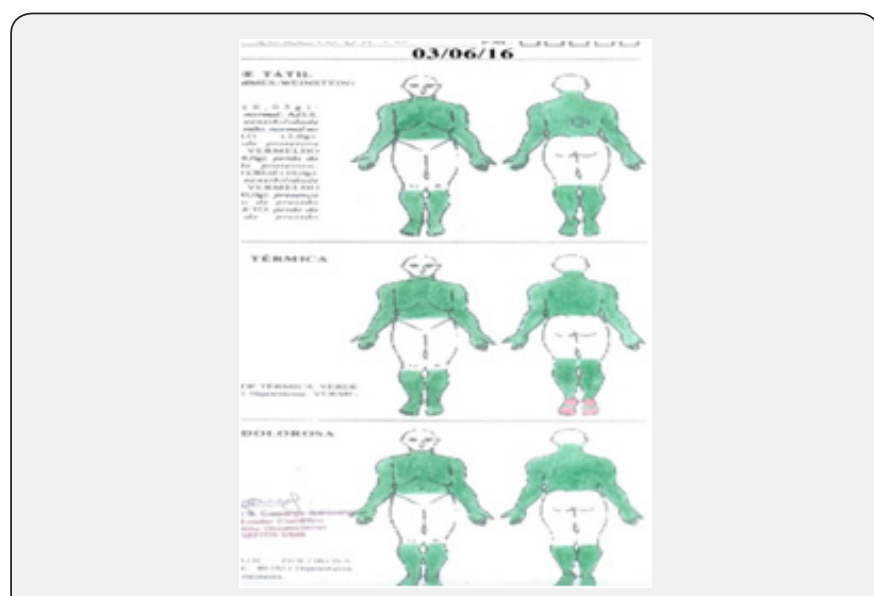

Figure 2: Normal sensory mapping: tactile, termal and pain modalities preserved in the thrunk and upper limbs.. 


\section{Juniper Online Journal of Dermatology \& Cosmetics}

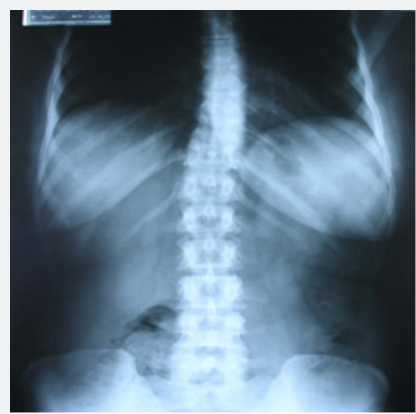

Figure 3: The spine X-ray with mild left dorsal scoliosis.

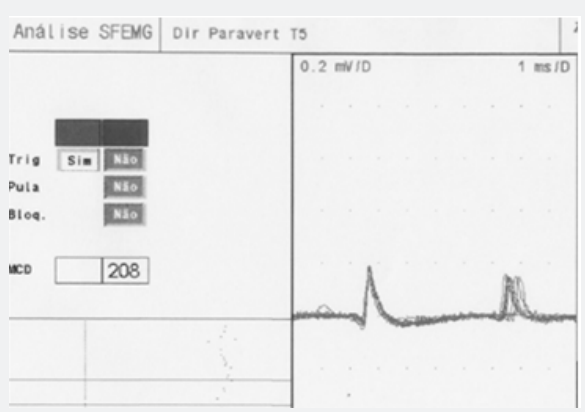

Figure 4: Single fiber EMG study showing increased jitter in the T5 level on the right side.

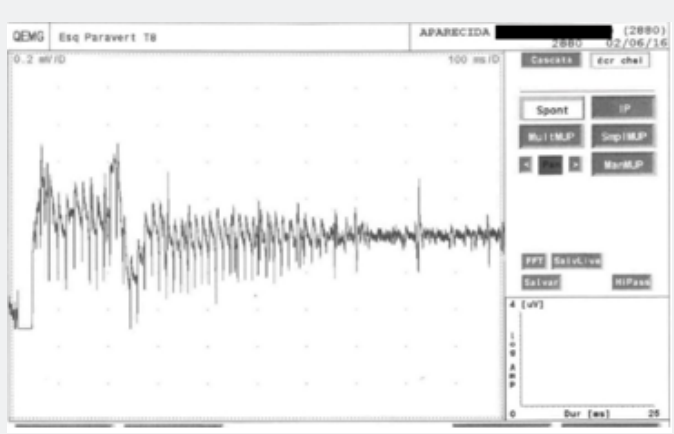

Figure 5: Pseudomyotonia recorded during the spontaneous activities analyses in the T8 level on the left side.

In neurophysiological approach the Electromyography (EMG) was the technique chosen to evaluate the dorsal roots because its has high sensitivity, specificity and reproducibility in radiculopathies [4]. The EMG showed mild chronic neurogenic motor pattern in dorsal paravertebral muscles of T3-T4 to T8-
T10 bilaterally and at the T8 and T9 level on the right side. In T5 level on the right, side increased jitter was recorded during single fiber EMG study, characterizing a chronic denervation and reinnervation process, with constant remodeling of the motor units [5], Figure 4. In T8 level, in the left side, pseudomyotonia was found during spontaneous activities analyses, a feature of axonal motor hyperexcitability, Figure 5.

\section{Conclusion}

In spite of being considered a sensory neuropathy [1,2], in the this case of PN no sensory loss was found, tactile, thermal and painful sensitivity in the involved territory associated with $A \beta, A \delta$ and $C$ fibers was normal. However, the motor evaluation showed root involvement in the symptomatic area. According to the literature, pruritus would be mediated by C fibers, similar to neuropathic pain, but due to the sustained hyperexcitability of these fibers due to itching and to a lesser extent by posttraumatic neuroplasticity [3]. These findings related to motor fibers in dorsal roots would reflect a picture of global intraneural hyperexcitability of the axons also involving nociceptive C-related fibers related to pruritus, as postulated about A-wave and pain in a previous papper [6].

\section{References}

1. Tyagi S, Kumar S, Kumar A, Singh G (2010) Pathophysiology and treatment of notalgia paresthetica-a sensory neuropathic syndrome of the back skin: an overview. International Journal of Pharma and Bio Sciences 1(3): 1-8.

2. Proença NG, Silva MF (2013) Notalgia parestésica: uma síndrome multidisciplinar. Arq Med Hosp Fac Cienc Med Santa Casa São Paulo 58: 38-41.

3. Azevedo RA, Kondo M, De Olivea ASB (2002) Prurido da Colestase. Rev Neurociências 10(3): 158-163.

4. Balbinot LF, Garbino JA, Riberto M (2010) Eletroneuromiografia na avaliação das radiculopatias cervicais e lombossacrais. Acta Fisiátrica, 17(4): 188-192.

5. Garbino JA (2010) A Eletromiografia de Fibra Única. In: Luiz Carlos Pinto; Vera Lucia Rocha Pinho. (Org.). Neurofisiologia Clínica, Princípios Básicos e Aplicações. ( $2^{\text {nd }}$ edn.). Rioi de Janeiro: Atheneu 1: p. 347-355.

6. Garbino JA, Naafs B, Salgado MH, Ura S, Virmond M, et al. (2011) Association between neuropathic pain and a-waves in leprosy patients with type 1 and 2 reactions. Journal of Clinical Neurophysiology 28(3): 329-332. 

(c) This work is licensed under Creative DOI: $10.19080 / J O J D C .2018 .01 .555559$

\section{Your next submission with Juniper Publishers} will reach you the below assets

- Quality Editorial service

- Swift Peer Review

- Reprints availability

- E-prints Service

- Manuscript Podcast for convenient understanding

- Global attainment for your research

- Manuscript accessibility in different formats ( Pdf, E-pub, Full Text, Audio)

- Unceasing customer service

Track the below URL for one-step submission https://juniperpublishers.com/online-submission.php 